\title{
What is BIM? A Need for A Unique BIM Definition
}

\author{
Dat Tien Doan ${ }^{1 *}$, Ali Ghaffarianhoseini ${ }^{1}$, Nicola Naismith ${ }^{1}$, Tongrui Zhang ${ }^{l}$, Attiq Ur Rehman ${ }^{2}$, John \\ Tookey ${ }^{l}$, and Amirhosein Ghaffarianhoseini ${ }^{l}$ \\ ${ }^{1}$ Department of Built Environment, Auckland University of Technology, 55 Wellesley St E, Auckland, New Zealand \\ ${ }^{2}$ Department of Building Construction and Services, Unitec Institute of Technology, 139 Carrington Road, Mt Albert, Auckland, \\ New Zealand
}

\begin{abstract}
Building Information Modelling (BIM) has rapidly developed in the construction industry recently; it is also considered as one of the core concepts in the Industry 4.0. However, BIM understanding is always seen as a significant problem for BIM implementation. Therefore, this paper aims to provide the insights into BIM awareness of the construction practitioners with the focus on the BIM definition in the New Zealand construction industry where BIM is still in its early stages. 22 interviews were conducted with 26 construction experts holding important positions in their companies and having at least eight years' experience in the industry. The results indicated that BIM has a variety of meanings to the interviewees. Four different definitions including Building Information Model, Building Information Modelling, Building Information Management, and Software/Technology were identified which was considered inappropriate, the fallacies of definition, for the construction industry. Also, most of the construction practitioners are seen as not well-aware of BIM, especially the SMEs. Furthermore, the results also indicated that the BIM survey potentially provided a false result at least regarding the BIM adoption rate in the New Zealand construction industry, which urges the BIM survey host to clarify the BIM definition before conducting the survey. The results of this paper are hoped to alarm the government and construction organizations to have a unique BIM definition for BIM development in New Zealand to ensure the consistent understanding among the industry.
\end{abstract}

\section{Introduction}

Building Information Modelling (BIM) has been widely acknowledging as an emerging concept being able to transform the whole construction industry. It could offer extensive changes in the way projects have been designed, built, and operated [1]. Various benefits of BIM have been researched to prove its potential impacts to the industry. For example, Newton and Chileshe [2] identified nine main benefits in South Australia while 18 BIM drivers were discovered by Eadie [3]. Also, benefits of BIM were divided into nine groups due to its "wide range of clear and current benefits associated with the use of BIM" by Ghaffarianhoseini [4]. In addition, using BIM in eight different countries including 35 cases were examined to determine the BIM impacts on the results of the projects [5]. Therefore, BIM has been considered as a game changer for the construction industry.

Following with the global increased interest in BIM development, the New Zealand construction industry started intriguing BIM. Although BIM in New Zealand has still struggled with itself in its early stages with slow uptake levels [6, 7] and insufficient attention from researchers [8], there have been few efforts initiated. A BIM handbook [9] and the BIM survey [10] have been kept continuously updating in order to offer the up to date information and knowledge to the construction practitioners. However, the first and foremost problem found here is the definition for BIM. Instead of having a common or unique BIM definition for the New Zealand construction industry, the BIM handbook has loosened the definition for BIM with a disinterested statement with what BIM is, "there are many definitions for BIM ... the focus will vary ..." [9] while the BIM survey [10] has not mentioned what BIM is in their results. Until the definition for BIM is discovered, the quality of the BIM handbook and BIM the survey are being questioned. This paper, therefore, aims to provide the insights into the BIM awareness with the focus on "what BIM is" in the New Zealand construction industry by conducting interviews with the key stakeholders in the industry. The findings are expected to be considered as baseline information for the next update of the BIM handbook and the survey along with the BIM understanding in New Zealand.

\section{Research methodology}

A qualitative approached was adopted in this study because of its benefits providing "deep, rich observational data" $[11,12]$. Specifically, semistructured interviews, allowing respondents the freedom to actively engage in sharing their views in their own terms [13-15], were conducted to examine the BIM perspectives of the key actors in the construction

* Corresponding author: dat.doan@aut.ac.nz 
industry. The data was collected through 22 interviews, 19 face-to-face and three telephone interviews, with 26 experts in the industry. 22 interviews were considered as the appropriate sample size in this study when the saturation of the information could be achieved. Galvin [16]'s and Guest [17]'s studies indicated that 12 interviews could be considered adequate for the qualitative approach while 20 and $15 \pm 10$ are the figures for the appropriate number of interviews stated by Crouch and McKenzie [18] and Kvale and Brinkmann [19], respectively. Also, similar sample sizes with this study were also found out in previous publications in the construction area such as Hurlimann [20]'s and Sacilotto and Loosemore [21]'s studies.

Table 1. Interviewees demographics

\begin{tabular}{|c|c|c|c|c|c|}
\hline Interviewee & Construction Position & Experience & $\begin{array}{l}\text { Construction } \\
\text { Type }\end{array}$ & $\begin{array}{l}\text { Company } \\
\text { Size }\end{array}$ & $\begin{array}{c}\text { BIM } \\
\text { Projects }\end{array}$ \\
\hline$\# 1$ & Senior Quantity Surveyor & 10 years & Contractor & Large & 1 \\
\hline$\# 2$ & BIM Manager \& GSAP1 & 14 years & Design & Large & $>50$ \\
\hline$\# 3$ & $\begin{array}{l}\text { Director, Building Scientist, } \\
\text { Green Star Assessor, \& GSAP }\end{array}$ & 12 years & Consultancy & Large & $>50$ \\
\hline$\# 4$ & $\begin{array}{l}\text { Senior Architect, GSAP, \& Green Star } \\
\text { Assessor }\end{array}$ & 15 years & Design & Large & 30 \\
\hline$\# 5$ & $\begin{array}{l}\text { Technical Services Manager, Design } \\
\text { Manager, } \\
\text { GSAP, \& Green Star Assessor }\end{array}$ & 22 years & Contractor & Large & 6 \\
\hline$\# 6$ & $\begin{array}{l}\text { 1) Director, Building Surveyor* } \\
\text { 2) Building Surveyor }\end{array}$ & $\begin{array}{l}\text { 1) } 14 \text { years } \\
\text { 2) } 4 \text { years }\end{array}$ & Consultancy & SME & 15 \\
\hline$\# 7$ & Principal \& Designer & 30 years & Design & SME & 4 \\
\hline$\# 8$ & Senior Cost Manager & 20 years & Consultancy & Large & 1 \\
\hline$\# 9$ & Project Director & 23 & Contractor & Large & 11 \\
\hline$\# 10$ & Building Services Technical Leader & 8 years & Consultancy & Large & 7 \\
\hline$\# 11$ & Director \& Building Performance Expert & 19 years & Consultancy & SME & 1 \\
\hline$\# 12$ & $\begin{array}{l}\text { 1) Senior Associate \&National BIM } \\
\text { Manager* } \\
\text { 2) Building Scientist }\end{array}$ & $\begin{array}{l}\text { 1) } 22 \text { years } \\
\text { 2) } 3 \text { years }\end{array}$ & Design & Large & $>50$ \\
\hline$\# 13$ & $\begin{array}{l}\text { 1) Associate \& Structural Engineer* } \\
\text { 2) Drawing Office Manager }\end{array}$ & $\begin{array}{l}\text { 1) } 10 \text { years } \\
\text { 2) } 19 \text { years }\end{array}$ & Design & Large & $>50$ \\
\hline$\# 14$ & Structural Technician & 8 years & Design & Large & 1 \\
\hline$\# 15$ & $\begin{array}{l}\text { Sustainability Leader, Green Star Assessor \& } \\
\text { GSAP }\end{array}$ & 13 years & Design & Large & $>50$ \\
\hline$\# 16$ & BIM Construction Manager & 11 years & Contractor & Large & 40 \\
\hline$\# 17$ & Technical Lead \& Senior Quantity Surveyor & 12 years & Multidiscipline & Large & $>50$ \\
\hline$\# 18$ & $\begin{array}{l}\text { BIM Consultant, Application Engineer, \& } \\
\text { Business Analyst }\end{array}$ & 17 years & $\begin{array}{l}\text { Information } \\
\text { Technology }\end{array}$ & SME & $>50$ \\
\hline$\# 19$ & Associate Senior Architect & 11 years & Design & Large & $>50$ \\
\hline$\# 20$ & $\begin{array}{l}\text { 1) BIM Development Engineer* } \\
\text { 2) Senior Structural and Sustainable Engineer, } \\
\text { \& GSAP }\end{array}$ & $\begin{array}{l}\text { 1) } 20 \text { years } \\
\text { 2) Unknown }\end{array}$ & Consultancy & Large & 50 \\
\hline$\# 21$ & Principal Quantity Surveyor & 8 years & Multidiscipline & Large & 2 \\
\hline$\# 22$ & GSAP \& Green Star Assessor & 10 years & Non-profit & Large & 0 \\
\hline
\end{tabular}

${ }^{1}$ Green Star Accredited Professional

*Corresponding interviewee

Regarding the sampling methods, the purposive sampling was initially utilized with criteria including the number of years working in the industry, at least five year's experience, and participating in a number of BIM projects before adopting the snowball sampling used to determine the BIM experts in the New Zealand construction industry. To ensure the quality of the information obtained from the participants as well as the quantity of the sample size, multiple sampling techniques are not uncommon in the qualitative studies $[22,23]$. The potential participants were initially approached using the LinkedIn source because of its powerful professional networking tool providing a large database of business professionals [24, 25]. Then, the rest of the interviewees were suggested by the former ones.

"To ensure that the privacy, safety, health, social sensitivities and welfare of human participants are 
adequately protected" [26], Ethics Approval was sought from the Auckland University of Technology Ethics Committee granted on 31 August 2017 (reference number: 17/309).

The interviewees demographics were described in Table 1. The interview recordings were transcribed before conducting the analysis. Due to the sound issues while recording the data from the interviewee $\# 9$, the transcript of \#9 was removed before doing the analysis. In other words, 21 transcripts were used for the later stages.

To ensure the validity and reliability of the findings, a combination of four different strategies were utilized including, maximum variation, adequate engagement, accuracy transcribing, and triangulation. Initially, maximum variation was achieved to enhance transferability of the findings to readers for their applications by purposely selecting a wide range of characteristics of participants $[27,28]$. It is clear from Table 1 that the interviewees came from various positions, years of experience, business types, company sizes, and a number of BIM projects which can provide a wide range of BIM perspectives. Then, the adequate engagement was also planned and carried out to ensure the sufficient time spent on the data collection to achieve the saturation of the data [28]. Also, the transcripts were checked to avoid mistakes during the transcribing stage [29-31]. Finally, triangulation, utilizing multiple sources of data to confirm the findings $[28,32,33]$, was conducted and presented in the following section.

\section{Results and Discussion}

In this section, three different themes were analysed and discussed including 1) What BIM is? 2) BIM knowledge of the New Zealand construction practitioners; 3) New Zealand BIM survey.

\subsection{What BIM is?}

What BIM is was initially asked to evaluate the interviewees' BIM perspectives to its definitions before gaining insights into BIM perspectives from them. Interestingly, four different types of BIM definitions were revealed from 21 interviews including Building Information Model, Building Information Modelling, Building Information Management, and software/technology. Building Information Modelling was mentioned mostly by the interviewees followed by Building Information Model, and Building Information Management.

Initially, BIM was defined as "a digital model of physical orbit environment" (\#1). In other words, "BIM is Building Information Model" (\#2), "a 3D model, the product itself, the model, do not care how it was made; it could be Revit, it could be ArchiCAD, whatever" (\#12), which is "the most well sort of recognized definition" (\#16). However, \#5 stated that "BIM is not just a $3 \mathrm{D}$ model, it is a complete collaborative working environment". "BIM is a process and a tool to deliver particular construction projects ... using collaboration as the keystone to the success through the use of digital tools and sharing information to enhance cooperation process" (\#21). "It is more observed as a process which is Building Information Modelling, which is an interactive approach between the designers, the consultants, the main contractor, and the rest of the supply chain from the main contractor to interactively come to give the solution and be able to actually construct what we have designed" (\#16). The next indicated interpretation is Building Information Management. "It is a way of bringing all the information about the project together" (\#4) in which "3D modelling, 3D coordination, or clashes detection is only one small part of it". \#13 mentioned Building Information Management as "a big workflow which starts from client concept through to architectural concept, structural concept, detailed design, and then through to construction". It is more important definition compared to the others which "control the people so that they actually understand how to do the job properly" (\#7). Finally, software/technology was mentioned as another understanding of BIM. "When I think of BIM, I think of Revit" (\#15) or "it is just using the technology that we have today to do things better" (\#10) were the opinions of two interviewees while the rest of them regarding BIM as a software, Revit, when they mentioned about the understanding of the other construction practitioners in New Zealand such as "a lot of people go, I am doing BIM because I am using Revit" (\#19). An explanation was provided for the reason why many construction practitioners still think BIM is a software as the following statement, "the thing with Autodesk is they use it as a marketing tool, so Revit is BIM, and now people associate BIM with Revit, it might be not a true sense in the bigger picture of what it could mean for me. It is probably a marketing tool for Autodesk" (\#4).

The findings are in line with existing literature indicating a diversity of BIM definitions. Turk [34] and Hjelseth [35] stated BIM as Building Information Model, Building Information Modelling, and Building Information Management; while Eastman [36] discussed the difference between Building Information Model and Building Information Modelling. Also, King [37] and Hongming [38] indicated a misunderstanding of BIM as Revit.

The fallacies of definition were defined as "overly broad, use obscure or ambiguous language, or contain circular reasoning are called fallacies of definition" [39]. It is noted that except \#3 and \#10, at least two different definitions were provided by each interviewee. In other words, there is no unified interpretation of BIM currently as stated by \#8, "even internally, you can ask every single person here, and they will have a different interpretation of what BIM is to them. At the moment, there is no consistency". This is considered as the criteria of the fallacies of definition mentioned above which may cause a significant problem regarding what BIM stands for. Therefore, there is a need for a unique BIM definition in New Zealand to ensure the consistent understanding among the construction practitioners; \#20 
supported this by stating that "things will change in the future, and I think that BIM may become a term that is only relative to coordination ... eventually, BIM may just become a different definition of 3D coordination ... BIM is probably going to be different now because that is not so Revit focus, maybe it is something completely different".

\subsection{BIM knowledge of the New Zealand construction practitioners}

To gain a deeper understanding of BIM among construction practitioners in New Zealand, the interviewees were asked whether the practitioners are well-aware of BIM. Negative feedback to the question was provided by half of the interviewees. BIM is considered as "a quite new concept" (\#1) in which "people do not even know what Building Information Management means" (\#13). Furthermore, "BIM in New Zealand is not utilized ... no one is really tapping into the full power of BIM" (\#4). \#18 even highlighted that "they all have 2D flat CAD thinking and mind flow ... what we have here is still that $75 \%$ of people working in that mindset". \#16 working at a tier one contractor in New Zealand revealed that "from my observations, most of the processes are still very paper-based". In conclusion, BIM is "still in its infancy stages" (\#6) or "the construction practitioners in New Zealand are not well-aware of BIM" (\#4). Except two interviewees believing that most construction practitioners are wellaware of BIM, the rest felt that it is a mix at the moment. They provided examples of BIM adoption from tier one contractor companies to support their opinions. (\#5) indicated that "we have got some key project managers and consultants to work with BIM, and most of the top tier contractors are fully aware of what BIM can offer" while "X does have a team for the BIM side ... Y and somebody else who also has the BIM team, whether or not they are implementing it to the maximum (\#2).

Despite the various perspectives of the interviewees, most of the construction practitioners in New Zealand are not well-aware of BIM could be rationally drawn owing to three main reasons: 1) the statement was approved by half of the interviewees; 2) tier one contractors in New Zealand were used as typical examples of key actors who are well-aware of BIM to support the mixed situation; however, two out of three top tiers contractors raised that "BIM is not very common yet" (\#16) in New Zealand. A BIM construction manager (\#16) at a tier one contractor company revealed the current awkward BIM adoption in his company as mentioned above; 3) all the interviewees from SMEs agreed with the statement while they are dominating the construction industry with $97 \%$ of the total companies in New Zealand [40]. The findings reflect the view of Rodgers [41] in which the low level of awareness comes from the SMEs dominating the industry.

\subsection{New Zealand BIM survey}

To examine the quality of the BIM survey [10] which was supported by prestigious organizations and companies in New Zealand, nine participants were asked about the result of BIM adoption rate, 57\% (many of them are working in the organizations and companies involving in the survey).

Interestingly, eight of the interviewees disagreed with the result of the survey regarding the BIM adoption rate. \#5 revealed that the BIM adoption rate in his company is around $30 \%$, half of the survey result; while \#8 remarked that “... even say $30 \%$ is high. I think that is more of an aspiration rather than reality. I would say probably between 10 and $15 \%$ of our projects are using BIM in its truest form", a sixth of the survey result. Also, \#16 strongly stated that "there is no way that they are about $60 \%$ of all the projects working that way at the moment". Then, explanations were provided from the participants to the number $57 \%$. \#12 pointed out that the survey "never defines what is BIM" while \#20 highlighted that "we have loosened the definition of BIM, so I am drawing in Revit, it is BIM". In the same vein, the rest of them believed that the BIM survey host and participants in the survey have the wrong understanding of what BIM is. It should be rewritten as $57 \%$ of the projects are using $3 D$ models which was suggested as "I do not think you can call it BIM, I think you should be calling it 3D" (\#17) or "they think they are dealing with 3D models ... that means it is BIM".

Besides the rejection of the BIM survey results from the interviewees, the results of the National BIM report in the UK [42] also indirectly reject the result of the survey in New Zealand. $62 \%$ is the proportion for the projects using BIM in the UK in 2017, quite the same as New Zealand. However, BIM is an attractive topic in the UK catching the interest from different types of people including construction companies, researchers, and policymakers. In 2011, the government had a five-year plan to mandate BIM level 2 by 2016 [42] and continuously keeping BIM as an important part of the strategy for the next five-year plan [43], along with releasing many standards, guidelines, classifications, deliveries, methods of measure for BIM adoption [44]. Furthermore, hundreds of research papers on BIM topics could be found in prestigious databases like Scopus or Web of Science. In contrast, the New Zealand government "is not interested in BIM" (\#18) while \#3 revealed that "the government and politicians do not know much about the construction industry or buildings". Consequently, \#18 indicated that the New Zealand government does not have a long-term plan and strategy for BIM adoption. Moreover, the researchers in New Zealand are disinterested in BIM, with only three journal papers in the Scopus database. Therefore, it is questionable when the figures for the BIM adoption rate are similar even though these two countries have two different approaches to BIM adoption. More interestingly, the BIM adoption rate in 2016 of New Zealand was even higher than that of the UK when BIM was mandated in the UK, 55\% compared to $54 \%$ [10, 42]. All of these proposed that the BIM survey potentially provided a false result at least regarding the $\mathrm{BIM}$ adoption rate in the New Zealand construction 
industry. There is a need to revise the way that BIM survey has been conducted, especially with the focus on the BIM definition.

\section{Conclusion}

This paper aims to provide the insights into BIM awareness of the construction practitioners in the industry with the focus on the BIM definition. 22 semistructured interviews with 26 construction experts were conducted and analysed. There are three themes including 1) What BIM is? 2) BIM knowledge of the New Zealand construction practitioners; 3) New Zealand BIM survey; analysed and discussed. The results indicated that there is a diversity of BIM definitions in New Zealand considered inappropriate, the fallacies of definition, for the construction industry. Also, most of the construction practitioners are seen as not well-aware of BIM, especially the SMEs. The result of the BIM survey was also asked to examine the role of the BIM definition which was missed in the BIM survey. Almost all the interviewees believed that there is a need for a BIM definition clarification before conducting the survey or when analysing the results. This is because of the various interpretation of BIM may causing the misunderstood by both the survey distributors and the participants. The results of this paper are hoped to alarm the government and construction organizations to have a unique BIM definition for BIM development in New Zealand to ensure the consistent understanding among the industry.

This paper is a part of a larger research project discovering the current BIM situation in New Zealand. Future studies will include the findings of the construction practitioners' BIM perspectives to the current barriers/challenges, potential benefits, and solutions for BIM adoption. Furthermore, interrelationships among those factor impacting the BIM adoption will also be analyzed with the aim to gain the insights into BIM development.

\section{References}

1. Ghaffarian Hoseini, D.T. Doan, N. Naismith, J. Tookey, A. GhaffarianHoseini, ECAM 24, 696-714 (2017)

2. K. Newton, N. Chileshe, ARCOM 28 (2012)

3. R. Eadie, H. Odeyinka, M. Browne, C. McKeown, M. Yohanis, ITcon 18 (2013)

4. A. Ghaffarianhoseini, J. Tookey, A. Ghaffarianhoseini, N. Naismith, S. Azhar, O. Efimova, et al., Renew. Sustainable Energy Rev. 75, 1046-53 (2017)

5. D. Bryde, M. Broquetas, J.M. Volm, IJPM 31, $971-$ 80 (2013)

6. I. Page, BRANZ (Report No. 283, New Zealand, (2013).

7. G. Miller, S. Sharma, C. Donald, R. Amor, PLM 13, 606-18 (France, 2013).
8. R. Amor, Y. Jiang, X. Chen, $C I B$ W78, 26-9 (Slovenia, 2007).

9. BAC, BAC (The New Zealand BIM Handbook, New Zealand, 2016).

10. EBOSS, EBOSS (BIM in New Zealand - an industry-wide view 2017, New Zealand, 2017).

11. S.D. Sieber, Am. J. Sociol. 78, 1335-59 (1973).

12. A.J. Onwuegbuzie, N.L. Leech, Int. J. Soc. Res. Methodol. 8, 375-87 (2005).

13. D. Cohen, B. Crabtree, RWJF (Qualitative research guidelines project, New Jersey, 2006).

14. A. Galletta, NYU Press (2013).

15. M.C. Harrell, M.A. Bradley, RAND Corporation, (2009).

16. R. Galvin, Journal of Building Engineering 1, 2-12 (2015).

17. G. Guest, A. Bunce, L. Johnson, Field methods 18, 59-82 (2006).

18. M. Crouch, H. McKenzie, Soc. Sci. Inf. 45, 483-99 (2006).

19. S. Kvale, S. Brinkmann, $S A G E, 230-43$ (US, 2009).

20. A.C. Hurlimann, G.R. Browne, G. Warren-Myers, V. Francis, Build Environ. 137, 235-45 (2018).

21. J. Sacilotto, M. Loosemore, CME, 1-14 (2018).

22. C. Teddlie, F. Yu, J. Mix Methods Res. 1, 77-100 (2007).

23. M.D.C. Tongco, ERA 5, 147-58 (2007).

24. W.D. Albrecht, AJBE 4, (2011).

25. K. Schneiderman, Career Planning and Adult Development Journal 32 (2016).

26. AUT, AUT (Applying for Ethics Approval: Guidelines and Procedures, New Zealand, 2018).

27. M.Q. Patton, Sage (US, 2015).

28. S.B. Merriam, E.J. Tisdell, Jossey-Bass (US, 2016).

29. J.W. Creswell, Sage (US, 2013).

30. G. Graham, Sage (UK, 2007).

31. J, Longhofer, J. Floersch, J. Hoy, Oxford University Press (UK, 2012).

32. R.M. Silverman, K.L. Patterson, Routledge (2014).

33. R.S. Barbour, BMJ 322, 1115-7 (2001).

34. Ž. Turk, Build Environ. 107, 274-84 (2016).

35. E. Hjelseth, WIT Trans. Built. Env. 169, 3-14 (2017).

36. C.M. Eastman, C. Eastman, P. Teicholz, R. Sacks, John Wiley \& Sons (2011).

37. M. King, Plumbing Connection, 74-77, (2011).

38. X. Hongming, Z. Huilong, C. Wenjing, L. Rui, JSAER 4, 333-6 (2017).

39. G. Gibbon, Rowman \& Littlefield (2013).

40. MBIE, MBIE (Small business in New Zealand: How do they compare with large firms? New Zealand, 2017). 
41. C. Rodgers, M.R. Hosseini, N. Chileshe, R. Rameezdeen, ARCOM 31 (UK, 2015).

42. NBS. NBS (National BIM report 2018, UK, 2018).

43. PA. IPA (Government construction strategy 201620, 2016).

BSI. BSI (B/555 Roadmap (June 2013 update), UK, 